\title{
THE MODEL OF LEARNING DESIGN BASED ON ISLAMIC MULTICULTURAL EDUCATION TO PREVENT CONFLICTS OF BEHAVIOR
}

\author{
Zaitun Syahbudin \\ Universitas Islam Negeri (UIN) Sultan Syarif Kasim Riau \\ Jalan H. R. Soebrantas KM. 15.5, Simpang Baru, Tampan, Pekanbaru 28293 \\ Email: zaitun@uin-suska.ac.id

\section{Muhammad Hanafi} \\ Universitas Islam Negeri (UIN) Sultan Syarif Kasim Riau \\ Jalan H. R. Soebrantas KM. 15.5, Simpang Baru, Tampan, Pekanbaru 28293 \\ Email:mhanafi@uin-suska.ac.id
}

Received: 04, 2017. Accepted: 12, 2017. Published: 12, 2017.

\begin{abstract}
This paper presents the form of multicultural conflict at SMA (Sekolah Menengah Atas/Senior High School) Kartini Regency of Rokan Hilir Riau, the supporting and inhibiting factors in application of the multicultural curriculum and design of learning model for multicultural-based PAI (Pendidikan Agama Islam /Islamic Education) to put down the conflicts among students. The research was a research and development $(\mathrm{R} \& \mathrm{D})$ with qualitative approach. Research and development were conducted up to hypothetical phase. The research subjects were the teachers of PAI, Chemistry, and PKN (Pendidikan Kewarganegaraan/Civic Education). Each of subject teacher was one person, and the number of participating students were 34 people. Data collection technique was conducted by observation, interview, questionnaire, and documentation. Qualitative data processing encompassesed data collection, reduction, presentation, and verification. Based on the research results, there were conflicts at SMA Kartini caused by individual differences, interest differences, cultural and social changes. The supporting factor in application of multicultural curriculum was that all stakeholders at SMA Kartini still have tolerant attitude which can be developed and directed and the teachers at SMA Kartini have inclusive attitude. Meanwhile, the inhibiting factors in application of multicultural curriculum at SMA Kartini were the minimum facilities and infrastructure, lack of information services, and lack of supervision towards students.
\end{abstract}

Keywords: Behavior Conflict, Islamic Education, Multicultural.

\begin{abstract}
ABSTRAK
Makalah ini memaparkan bentuk konflik multikultural di SMA Kartini Kabupaten Rokan Hilir Riau, faktor pendukung dan pengbambat diterapkannya kurikulum multikultural, dan desain model pembelajaran pendidikan agama Islam (PAI) berbasis multikultural untuk meredam konflik dikalangan peserta didik. Penelitian merupakan penelitian pengembangan dengan pendekatan kualitatif. Penelitian pengembangan dilakukan sampai pada fase bipotetik. Subjek. penelitian adalab Guru PAI, Kimia dan Pendidikan Kewarganegaraan (PKN) masing-masing 1 orang dan peserta didik berjumlah 34 orang. Teknik pengumpulan data dilakukan dengan cara observasi, wawancara, angket dan dokumentasi. Pengolahan data kualitatif meliputi koleksi data, reduksi, penyajian, dan verifikasi. Hasil penelitian diperoleh data babwa konflik di SMA Kartini disebabkan oleb perbedaan individu, perbedaan kepentingan, budaya dan perubahan sosial. Faktor pendukung diterapkanny a kurikulum multikulural di SMA Kartini adalah selurub stakeholder di SMA Kartini masib memiliki sikap toleransi yang dapat dibina dan diarabkan dan guru di SMA Kartini memiliki sikap inklusif. Sementara itu faktor penghambat diterapkannya kurikulum multikultral adalah minimnya sarana dan prasarana, kurangnya layanan informasi, dan kurangnya pengawasan terbadap peserta didik.
\end{abstract}

Kata Kunci: Konflik, Pendidikan Agama Islam, Multikultural. 


\section{INTRODUCTION}

Indonesia is one of the biggest multicultural countries in the world. The circumstance can be seen from the wide socio-culture and geography with diversity of ethnic groups, religions, races and culture (Kariyawan, 2012). The wave of democracy demands the difference in Indonesia as a pluralistic nation. The multicultural education is the answer to settle the process diversity problem (Tonbuloglu, Aslan, \& Aydin, 2016). Realizing that education is the process of cultivation and the prospect of the united nations referring to the elements of Indonesian culture (Tilaar, 1999). Indonesia, as country with various of ethnics, groups, cultures, and religions, can simply be called as a multicultural society.

The diversity of ethnic groups which is one of the characteristics of Indonesian society can be a pride. However, the diversity can also be a source of conflict that can threaten the unity and life of Indonesian nation. It is obvious that due to the fact that Indonesia is a multicultural country with different ethnicities, cultures, and religions, the conflicts among them frequently occur. One effort to minimize the conflict is through schooling-educational institutions. The school refers to an institution that introduces differences in religions, cultures and ethnicities. As an institution that provides the introduction and cultivation of values and virtue, the school is expected not only to transfer knowledge but also to transfer values. Transferring values means teaching religious and cultural values from the previous generation to the next generation. So, it is expected that the institution can solve and minimize the rise of conflict.

School has an important role in forming the individual character in classroom. One of the strategic duties of the school is to create the tolerant attitude so that the relation among the groups can bind up in harmony and peace. Furthermore, the school through multicultural education can help students decrease the potential conflicts in education setting. The multicultural education is a response to the development of the diversity of school populations as well as the demands of equal rights for each group. In another dimension, it is the development of a curriculum in educational activities that is expected to enter various views, histories, achievements, and attention to people of other ethnicities. This means that multicultural education extensively covers all students regardless of the groups, be it ethnicity, race, culture, social strata, religion, and gender so as to be able to deliver students into tolerant and respectful human beings (Arifudin, 2007; Banks, 1993).

Through multicultural education, a school which students come from the various backgrounds are guided to introduce each other to the difference of ethnicities, religions, cultures, and lifestyle (Sugimura, 2015). Thus, the students may be guided early to understand the aim of Bhinneka Tunggal Ika and implement it in their learning process. Furthermore, there is a need to design a multicultural-based learning model, which is able to face the multicultural problems in their life.

Rokan Hilir, which is one of the regencies in Riau Province and the main city of Bagan Siapi-api, is very heterogeneous with multi-race, ethnicity, and religion. Here live Javanese, Batak, Minang, Melayu, and Tionghoa. It may lead to heterogeneity conflict. The conflict is the economic domination by Chinese ethnicity cannot be faced by indigenous people some of which, even, work for them.

SMA Kartini at Panipahan village, the Sub-district of Pasar Lima Kapas, refers to a school that accomodates the multicultural students. The school does not only belong to Tionghoa but also Muslim. This condition potentially triggers the emergence of conflicts among different ethnicities, cultures, and religions such as being difficult to do team work, tendency to humiliate other students, and being deliberately introverted students. If it is not immediately overcome, it can be a trigger of conflict. Therefore, the teachers should be professionally able to design the learning model of multicultural-based Islamic education to minimize the conflict (Alismail, 2016). 
Based on the explanation above, this paper presents the form of multicultural conflict at SMA Kartini, the supporting and inhibiting factors in application of multicultural curriculum, and presents design of learning model for multicultural-based PAI. It is expected that this finding of learning model for multicultural-based PAI can put down the conflicts among students.

\section{METHOD}

This research was qualitative in nature and it applied research and development (R\&D) that just get on to hypothetic level. The research design is shown in Figure 1.

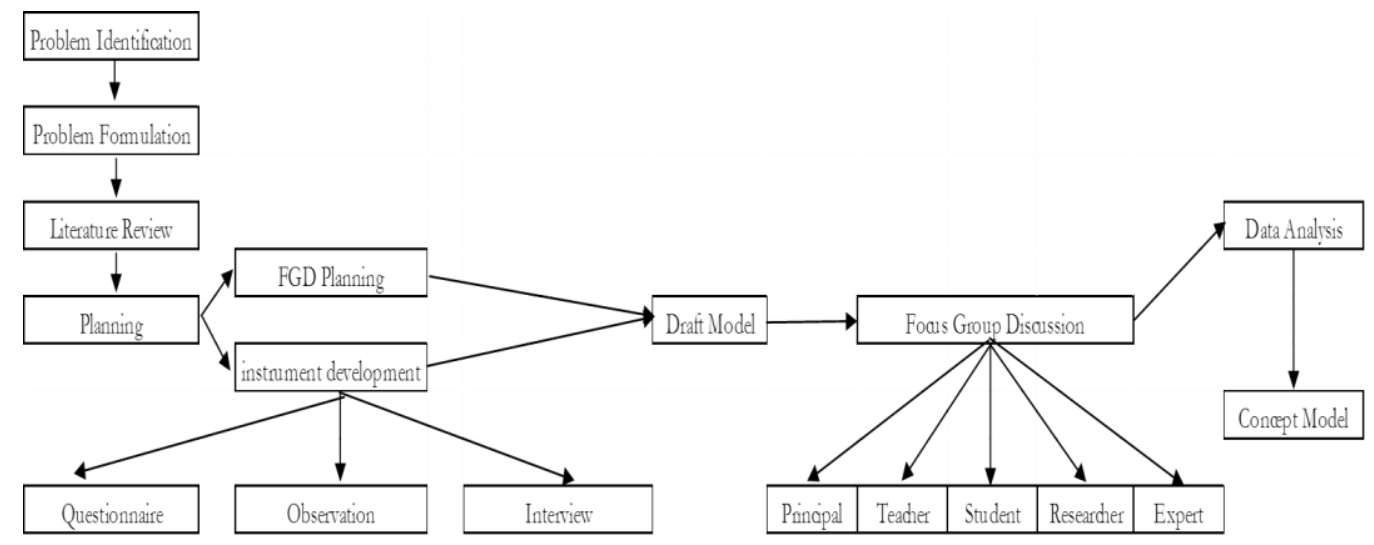

Figure 1. Research Design.

The research was conducted at SMA Kartini Rokan Hilir Regency. The research subjects were the teachers of PAI, Chemistry, and PKN and the students in the grade XI consisting 34 students at SMA Kartini.

The techniques of data collection were observation, interview, questionnaire and documentation. The observation was used to observe the process of learning that happens to cause conflict. The interview was used for teachers of PAI, Chemistry, and PKN to find the teachers' perspectives of the learning process. The questionnaire was intended to gather information on students' attitude toward the model of learning that was used by the teacher. The documentation was related to school data. The process of the qualitative data analysis was conducted by using the steps: (1) data collection, it was accomplished using observation, interview, questionnaire and documentation. In addition, field notes and interview were also used to gain more data; (2) data reduction was committed by re-writing and typing the selected data in essay form or the clear report. This report was meant to reduce, summarize, and select systematic and important data; (3) data display was the effort to see the description by all of sides from the data research. Therefore, the data were shown in a various of matrix, graphs, and chart; and (4) data verification was the effort to find the means of data that were collected for interpretation. The tabulation of data was carried out by verifying and clarifying the data that have been collected to make them objective and systematic.

To gain the valid data, the researcher carried out the triangulation. The triangulation was committed by comparing and reviewing the data which were obtained by results of observation, interview, and the related theories.

\section{RESULTS AND DISCUSSION}

\section{The Form of Multicultural Conflict at SMA Kartini in Rokan Hilir}

There are many kinds of conflicts that are faced by the people in the daily life. There are various conflicts such as the conflict that is begun from themselves, school environment, 
society, between local, national, and international organizations until the conflict that happens between the group of countries and nations. The background of the conflicts is the differences within interaction. These differences may be related to physical appearance, intelligence, knowledge, customs and belief. In line with this, the information from the teachers revealed that:

The learning process which involved multicultural students had contributed to the emergence of conflicts in the school. Some of the conflicts that happened at SMA Kartini due to this multiculturalism were: the conflict between individuals, cultures, interests, and social changes Dahlan (Budiman, personal communication, September 9, 2016).

The condition of students that were plural in ethnicity, religion, and geography had contribution toward the social problems such as social imbalances, the conflict among groups, and ethnicities (Siregar, personal communication, September 9, 2016).

The form of conflict often happened at SMA Kartini; such as unhappy feelings, hate and yearn from someone or groups, all of which could destroy a relation. Besides that, there was a difference of opinion from the groups that caused a problem (Purba, personal communication, September 9, 2016).

The conflict happened in multicultural context at SMA Kartini was caused by the differences of individual interests, culture, and social change which had created social imbalances and conflict among groups and ethnicities. This follows Soekanto \& Sulistyowati (2013) opinion that there are four factors that cause conflicts to happen. They are the difference between individual, culture, interests, and social change. Therefore, some conflicts happened due to the different needs to manage and resolve based on the principles of humanism, as proposed by multiculturalism movement.

The followings are the clearer picture of the conflicts:

1. Differences between individuals.

Individual differences are differences that involve feelings, opinions, or ideas relating to one's self-esteem, pride, and identity. For example, there are students who want a quiet learning atmosphere but other students want to learn while singing, because according to the students learning while singing is very effective for them. Then anger arises on the other students, resulting in conflict.

2. Cultural differences.

A person's personality is formed by family and society. Not all communities have the same values and norms. What is considered good by one society is not necessarily good by the other. Social interaction between individuals or groups with opposing cultural patterns can create a sense of anger and hatred that result in conflict.

3. Differences of interest.

Each group or individual has different interests. These differences of interest can lead to conflict between them.

4. Social change.

Rapid change in society can disrupt the balance of the value system and prevailing norms. Consequently, conflicts can occur because of a discrepancy between individual expectations and the community. For example, young people want to overhaul the behavior patterns of their traditional society, while the old want to maintain the tradition of their ancestors, then the condition will cause conflict between them. 


\section{The Supporting and Inhibiting Factors in Implementation of Multicultural Curriculum at SMA Kartini}

The main factors stimulating the conflicts at SMA Kartini were the existence of diversity of ethnic groups, religions, and cultures. Based on interviews with the teachers, they revealed that the reasons behind the implementation of multicultural-based learning curriculum were: (1) all stakeholders at SMA Kartini still had attitude of tolerance which could be developed and directed; (2) teachers at SMA Kartini had inclusive attitude. They could accept the differences existing at SMA Kartini and could adapt themselves with students from various ethnic groups, religions, cultures, economic circumstances, and academic abilities. On the other hand, the inhibiting factors in application of multicultural curriculum at SMA Kartini were the minimum facilities and infrastructure, lack of information services, and lack of supervision towards students. As Purba said:

The inhibiting factors in the implementation of curriculum in multicultural learning are the condition of society and the students' narrow mindset, students' lack of understanding and belief in multicultural values and also because the curriculum does not generally include multiculturalism in the policy of the national curriculum (Purba, personal comunication, September 9, 2016).

\section{The Curriculum of Multicultural SMA Kartini}

The curriculum of multicultural education at SMA Kartini was not yet available; however, the implementation of multiculturalism was carried out in particular subjects (Siregar, interview, September 9, 2016). This was done by Supardi (2014) and Utomo (2016) who implemented multicultural education developed through History Subject.

At SMA Kartini, the curriculum integrated the implementation of multicutural learning. It can be seen from the design of lesson plan and the application of multicultural learning which was integrated into the class theme. SMA Kartini evaluated and revised itself the designed curriculum by using the theory of development of teenage. The teacher designed the lesson plan by using the indicator that was suitable with students' age and ability.

The curriculum used in multicultural learning at SMA Kartini was the curriculum that was made by the school itselfs. The curriculum had its typicalities in its implementation. The curriculum covered values such as inclusive, focus on the students, multiple intelligence, universal value, environmentally friendly life, respect of local wisdom, independent and creative, and gender fair. Clarifications of the typicality are as follows.

1. Inclusiveness.

Inclusive at SMA Kartini means that the school accepted students with physical, ethnical, cultural, intellectual, language, economic and social differences. SMA Kartini gave opportunities and the equal rights for students in obtaining the proper educational services for all students. Teachers were in the position to fully understand multiculturalism in order to educate the students equally (Alismail, 2016).

2. Student-centered.

SMA Kartini applied the inclusive curriculum that should be able to provide facilities and infrastructure, method of teaching, and evaluation system adjusted with heterogeneous students' needs. Therefore, in its arrangement, students become the main focus.

3. Multiple intelligence.

SMA Kartini gave freedom and facilitated students to increase and use the plural intelligence they had. The plural intelligence is the linguistic, mathematical, spatial, kinetic and physical, musical, interpersonal, intrapersonal, and naturalist intelligences. 
4. Universal value education.

Education of value developed at SMA Kartini was universal value. The universal values are: (a) peace: thinking positive about themselves and other people; (b) appreciation: appreciating themselves and treating other people properly and well; (c) love: keeping, paying attention, sharing, and being friendly one another; (d) responsibility: doing the work by themselves, keeping, and caring for; (e) happiness: being loved, doing good things, having good hopes for other people; (f) collaboration: helping each other to finish a job patiently and wholeheartedly; (g) honesty: telling the truth (h) humbleness: knowing the strengths but not boasting; (i) tolerance: being able to accept the own self and other people and accept the diversity; (j) simplicity: using what we have and not having wasteful characteristic; (k) unity: harmony in groups, making us like one family.

5. Friendly milieu.

Attitude of friendly milieu at SMA Kartini had four principles; reducing, reusing, recycling, and replanting.

6. Respecting local wisdom.

SMA Kartini developed curriculum trying to conserve and develop various local wisdoms. Multicultural curriculum which implanted to students refers to local government's policy, local culture, local language, diversity of ethnic groups and utilizing the surrounding resources.

7. Independent and creative.

SMA Kartini helped to facilitate students to develop their independence and creativity. Independence and creativity needed by students to adapt to their daily life. The independence refers more to freedom than to their needs. This is strictly related to ability of undergoing the life, considering choices, and making decision by themselves. Creativity focuses more on process of thinking out of the box. Being creative is meant as the ability to accomplish some problem with various ways.

8. Gender-just.

SMA Kartini gave equal chances to all school stakeholders (teachers, staffs, students, and parents) without distinguishing the gender. They had the equal chances and rights in school services.

When making the class program, the teachers considered children's development level. As one teacher explained:

I find information about every student by doing observation and needs analysis to the syllabus through the analysis of students' grades and attitude. The result of these analyses becomes the reference to decide the class program (Marintan, personal communication, September 8, 2016).

This is in line with what the chemistry teacher said that:

In designing the lesson plan, I do placing the students' seat which accommodates heterogeneous students in terms of ethnicity and knowledge, giving feedbacks in learning process, and giving reward or appreciation to the students who respond to teachers' questions (Siregar, personal communication, September 9, 2016).

The teacher involved the student to plan classroom activities. The students had chances to express their ideas concerning activities they want to do. The teacher also gave a sense of responsibility to their students to think about what activity to include that relates to class theme. 
We usually invite the students and ask them what activity that will be done, and say to them our activity will be like this tomorrow, or the students will be invited to make activity for one week that is suitable with their theme. Sometimes we follow the students' ability, and review particular area (topic) again. Even, some students are bored to play that area again" (Budiman, personal communication, September 9, 2016).

In designing multicultural lesson plan, teacher should consider students' development and background and also invite them to participate in designing process. The teacher arranged multicultural lesson plan to develop students' attention also invite them in arranging class activities. The teacher informs the students that there are going to make a class program. Then the students were required to give an idea for the activity. The teacher wrote the idea and activity integrated by indicator that would be reached for a week in the class program. The teacher applied multiculturalism and it was integrated to the theme class by taking positive values that were in theme class related to multicultural values. The teacher discussed the values together with the students and applied them into their daily life in the class. The teacher coordinated it all in the class, such as the students' idea, class theme, and what method that will be used, so that all of them could be applied into the process of multicultural learning.

Learning activity in the class was integrated with the theme that have been agreed by the students. The class theme of SMA Kartini was suitable with the agreement between the teacher and the students in the class. The theme was useful in learning to build interest and stimulate knowledge of the students through the contexts they were familiar with. The theme was the basic subject in doing learning in the class. The observation data in learning process in class and the result showed that theme in the class was integrated with the multicultural values. The teacher took positive value that was gotten from the theme then it was matched with the local culture of students' immediate surroundings. The teacher invited the students to study and implement the positive values they have learned in the class in their daily life. The application of multicultural learning was integrated to the theme in the class in evidence in their tolerance of differences, and also gives suggestion to develop each individual student's characters (Siregar, personal communication, September 9, 2016).

The learning that was integrated with the theme can also be integrated with education of multicultural value. The students were invited to study and see the differences in their surroundings. Through this activity, students were made to be aware to the differences existing among them. The way was by having teachers pose questions to the students such as: Who is a Muslem? Who is Christian? Who is Catholic? Who is Buddhist? By this, the students will realized that differences were there in their environment, especially in their near environments, namely their class room. The students become aware that their friends who were in the classroom were from different religions.

The application of multicultural learning was integrated to the theme in the classroom. The teacher should take positive values from the class theme relate to multicultural value. Doing multicultural learning feels difficult to do when the teacher was not ready yet to accept differences. The teacher was the spearhead in implementing multicultural learning in the class. The teacher's understanding of the multicultural values was so important. It affected the implementation of curriculum in multicultural learning. A teacher who did not understand the multicultural values may do something which is only based on what he/she believes and wants without considering the diversity around him/her.

\section{The Activity of Multicultural Learning at SMA Kartini}

In order to create learning, SMA Kartini was trying hard to cultivate the multicultural values in learning process. According to one teacher: 
I integrate the values covering: appreciating different opinion among students, appreciating the differences in heterogeneous groups, appreciating the students' work, and appreciating students' variety in friendship (Siregar, personal communication, September 9, 2016).

In relation to this, one teacher said:

The development of the material should include, planning and doing learning activity in helping the students to understand the purpose of learning and stimulate them to understand and master the concept in subject being taught (Siregar, personal communication, September 9, 2016).

Next, another teacher added:

The roles of the teacher are giving direction, applying the multicultural values for the students, giving a model, giving advice or guidance and also doing assessment for the values that have been taught to the students (Purba, personal communication, September 9, 2016).

The learning activity that contains multicultural values in the classroom of SMA Kartini was that, the teacher always made the students used to appreciating everyone's opinion without seeing the difference. In addition, the teacher often made activity together, where the students could apply democratic values in learning process.

The implementation of multicultural learning at SMA Kartini was integrated in classroom activities. The integrated activity invited the students to discuss each other, express opinion, give comment, ask, listen to story and play together. The teacher always appreciated the childrens as having human rights such as the freedom right and reach happiness. Despite their different backgrounds, all students deserved the same rights.

Unlike multicultural education practice in SMA Kartini, multicultural education practice in Malaysia is teacher centred. Teachers are actively involved in the delivery and students listen to receive information conveyed by the teacher. The methods used in this teacher-centered strategy was varied. Among these methods are methods of advice, explanation, glance back, gradual, speaking, story telling, contextual, lecture, and discussion. In the existing learning situation, the teacher uses an indirect approach. The approach is done by modeling current issues and relating them to daily life. From the examples of current issues, it is hoped that the good values of different cultures can be practiced in everyday life. This approach gives students awareness of the importance of unity in life and avoids doing things that can cause division among students (Omar, Noh, Hamzah, \& Majid, 2015).

The implementation of multicultural learning at SMA Kartini emphasizes the background and the children's needs. The teacher should know the students' background related to their cultural, social, economic, religious, physical, language, and emotional developments. The teacher made the activity that is suitable with the characteristic of development, namely giving stimulation in the five of development aspects that consist of: 1) physical and motoric development; 2) cognitive development; 3) emotional development; 4) social development; 5) language development.

Multicultural learning at SMA Kartini always sees the students' need and achievement of each students. Learning activity that is frequently done at SMA Kartini is by using various methods of learning design. As expressed by one of the teachers that:

The method that is applied in learning is jigsaw learning method, cooperative, contextual teachinglearning, using multimedia, problem-based learning, quantum teaching, and saintific approach (Siregar, personal communication, September 9, 2016). 
According to another teacher:

The suitable ways to deal with the students who have different backgrounds are learning to accept their difference and background, understanding the background, and solving students' problems by taking their characters and their backgrounds into account (Purba, personal communication, September 9, 2016).

Next, it is added from another teacher that:

To deal with the students that have different backgrounds are by making them understand that human beings have different characters and accept the difference as a means to unite in life and also respect each other (Siregar, personal communication, September 9, 2016).

At SMA Kartini, the teacher always gives the same chance to the students, without seeing gender, religion, economic background, need, language. Each student was free to express their opinions, comments, asking questions, and expresstheir feelings and wants. One of the example activities give a freedom to give opinion when choosing what activity that will be done. Each student was given a chance to express their idea. Therefore, the teacher was expected to be able to create the learning democratic process. The ways committed by the teacher in creating learning democratic process were by appreciating different opinion, giving the same freedom to each student to express their opinion, and respecting every student's right (Purba, personal communication, September 9, 2016).

The implementation of multicultural learning at SMA Kartini always invited the students in all sides in doing the activity learning. It includes preface activity, main activity, and closing activity. Example of all stages of multicultural learning at SMA Kartini can be seen in the following presentation.

1. Introduction activity.

On introduction activity, teacher always invited students to remember the class theme by submitting a question "what is today's theme?" The teacher also invited the students to recall the activities on previous days which have been carried out. Every student was given the same chance to tell what they had remembered about the activities on previous days. Then, teacher invited students to do the beginning webbing; that is, teacher's beginning step to gain information of how far the students understand the theme, whether they already knew much about information of theme or they do not know at all. This becames the teacher's grip to discuss the theme and the class activities which will be done.

2. Learning core activity.

In core activity, students were invited to discuss to determine the activities which would be carried out in the class. Teacher gave a chance to all students to express their opinions or ideas. When a student expressed an opinion, the teacher and other students listened and gave comments or questions related to the activities delivered. If there was an argument during discussion, teacher acted as mediator. Observation result from the discussion in the class shows that teacher gave the same chance to all students without distinguishing gender, religion, race, economic background, need, language and so forth. Every student was free to give opinions, comments, questions, and expressed their feelings and needs. From the observation result, it can be concluded that SMA Kartini tried to implant the multicultural values on the learning process. Teacher familiarized students to appreciate each other.

3. The closing activity.

4. On the closing activity, the teacher made conclusion, gave feedback towards the learning process, did reflection, gave information about the next activity, and did evaluation. 


\section{Students' Attitude towards Model of Multicultural Learning}

Data about students' attitude towards the model of multicultural learning were acquired from questionnaire. The results of spreading the attitude scale and the score of each answer alternative can be seen in Table 1. Data from Table 1 show that the students at SMA Kartini have positive responses towards the multicultural elements.

Table 1. Frequency and Percentage of Students' Questionnaire Answers.

\begin{tabular}{|c|c|c|c|c|c|}
\hline \multirow[b]{2}{*}{ No. } & \multirow[b]{2}{*}{ Questions } & \multicolumn{4}{|c|}{ Percentage $(\%)$} \\
\hline & & $\begin{array}{c}\text { Very } \\
\text { Agreeable }\end{array}$ & Agreeable & Disagreeable & $\begin{array}{c}\text { Very } \\
\text { disagreeable }\end{array}$ \\
\hline 1. & Must master the multicultural materials. & 29 & 61 & 10 & 0 \\
\hline 2. & $\begin{array}{l}\text { Must know about the existence of diversity of } \\
\text { nation's cultures as social reality, as form of } \\
\text { multicultural and plural society, so it is necessary to } \\
\text { form the democratic, dialogic, open and critical } \\
\text { behaviors. }\end{array}$ & 65 & 35 & 0 & 0 \\
\hline 3. & $\begin{array}{l}\text { Must know the importance of appreciating and } \\
\text { respecting each other among social members with } \\
\text { various backgrounds, cultures, religions, races, } \\
\text { ethnicities, genders, et cetera. }\end{array}$ & 84 & 16 & 0 & 0 \\
\hline 4. & $\begin{array}{l}\text { Must know the importance of rights equality, social } \\
\text { justice, and collective participation as social } \\
\text { members. }\end{array}$ & 39 & 61 & 0 & 0 \\
\hline 5. & $\begin{array}{l}\text { Must know the importance of conserving the } \\
\text { diversity of nation's cultures both local and national, } \\
\text { so that it brings about appreciation among cultures. }\end{array}$ & 58 & 42 & 0 & 0 \\
\hline 6. & Must understand the multicultural values. & 13 & 81 & 6 & 0 \\
\hline 7. & $\begin{array}{l}\text { Must understand the democratic interaction } \\
\text { patterns and appreciate the diversity of ethnic } \\
\text { groups, cultures, races, religions and genders. }\end{array}$ & 74 & 26 & 0 & 0 \\
\hline 8. & $\begin{array}{l}\text { Must have open attitude towards diversity of ethnic } \\
\text { groups, cultures, races, religions and genders. }\end{array}$ & 42 & 58 & 0 & 0 \\
\hline 9. & $\begin{array}{l}\text { Must be sensitive to social justice without making a } \\
\text { problem out of cultural backgrounds. }\end{array}$ & 7 & 93 & 0 & 0 \\
\hline 10. & $\begin{array}{l}\text { Must apply the multicultural values in students' lives } \\
\text { both in narrow environment and in wide one. }\end{array}$ & 42 & 58 & 0 & 0 \\
\hline 11. & $\begin{array}{l}\text { Must apply religion's positive values and culture's } \\
\text { glorious values in building the peaceful and united } \\
\text { society }\end{array}$ & 52 & 42 & 6 & 0 \\
\hline 12. & $\begin{array}{l}\text { Must have the positive behaviors towards } \\
\text { democratic attitude and social justice. }\end{array}$ & 45 & 55 & 0 & 0 \\
\hline 13. & $\begin{array}{l}\text { Must have the positive behaviors towards } \\
\text { togetherness and collaboration. }\end{array}$ & 61 & 26 & 13 & 0 \\
\hline 14. & $\begin{array}{l}\text { Must have ability of interacting and internalizing as } \\
\text { social creatures among the diversity of ethnic } \\
\text { groups, cultures, races, religions, and genders. }\end{array}$ & 52 & 48 & 0 & 0 \\
\hline 15. & $\begin{array}{l}\text { Learning process forms students' multicultural } \\
\text { personality. }\end{array}$ & 52 & 48 & 0 & 0 \\
\hline 16. & Must believe in God. & 94 & 6 & 0 & 0 \\
\hline 17. & $\begin{array}{l}\text { Must be able to communicate cultural ethic by } \\
\text { showing respect, appreciating other's culture, in } \\
\text { interaction and socializing in multicultural society }\end{array}$ & 36 & 64 & 0 & 0 \\
\hline 18. & $\begin{array}{l}\text { Must understand technology advancement as a } \\
\text { result of multicultural society that are advanced in } \\
\text { innovation and creation. }\end{array}$ & 55 & 45 & & \\
\hline
\end{tabular}

\section{Model of Learning Design for Islamic Multicultural-Based Education}

Multicultural notion is closely associated with pluralism. Historically speaking pluralism and multicultural educations actually have begun to emerge becoming a review. The pluralism education is an education supposing us to open vision on a wider firmament and being able to cross the limits of ethnic groups or cultural traditions and our religions, so that being able to see 
the humanity as a family having differences and similarities of aspiration. This is the education of humanism basic values for peace, independence, and solidarity (Naim \& Sauqi, 2008).

Multicultural education is a progressive approach to transform the education which comprehensively exposes weaknesses, failure, and practices of discrimination in process of education. Dawam (2003) explains that the multicultural education is the process of developing all human beings' potencies appreciating their pluralist and heterogeneity as a consequence for diversity of cultures, ethnicities, ethnic groups, and sects of (religion). The understanding of multicultural education certainly has a very wide implication in education, for the education itself is generally understood as process without end or lifetime process. Thereby, the multicultural education wants the respect and appreciation highly towards human beings' degree and dignity wherever they come from. Its hopes are creating real peace, security which is not obsessed, and happiness without being engineered.

Pluralism and multiculturalism are two different things; however, both of them have a very close relationship and are related each other. In context of society, plural society is absolutely different from multicultural society; nevertheless, the plural society is the basis for arrangement developing multicultural society, where the society and the culture interact and communicate intensely.

In context of Islamic education, pluralist-multicultural is the attitude of accepting pluralism of human beings' cultural expressions in understanding the religion's main messages. Its main bases are explored based on Islamic teachings, as the Islamic dimensions become the distinguishing bases as well as the pressing point from construction of education itself. The use of word 'Islamic education' doesn't meant to emphasize other religions' teachings or nonIslamic education; however, as a matter of fact to strengthen that Islam and Islamic education are full of the teachings which appreciate pluralist-multicultural dimension. Moreover, the Islamic education itself has existed and has typical characteristics, especially in discourse of education in Indonesia. The use of 'pluralist-multicultural' term stringed up by the word 'Islamic education' is meant to build a paradigm as well as theoretical and applicative constructions appreciating the diversity of religions and cultures. Such Islamic construction is oriented to process of awareness having religiously pluralist insight as well as having multicultural insight.

There are some aspects which can be developed from the concept of Islamic pluralistmulticultural education. Firstly, Islamic pluralist-multicultural education is the education which appreciates and embraces entire forms of heterogeneity. Thereby, it is expected that wisdom will grow in seeing entire forms of existing heterogeneity. Secondly, Islamic pluralist-multicultural education is a systematic effort to build students' understanding, comprehension, and awareness toward pluralist-multicultural reality. This is important to do because without systematic effort, reality of heterogeneity will be understood sporadically, fragmentarily, or even elicit an extreme exclusivity. On this point, heterogeneity is judged and viewed inferiorly. Even there may grow a wish to do authorities and ambitions of conquering the different them. Thirdly, Islamic pluralist-multicultural education does not compel or refuse students due to identities of ethnic groups, religions, races or classes. Those who come from various diversities must be positioned equally, in egalitarian way, and be given precise medium to appreciate the characteristics which they have. In such condition, there is nothing more excellent between one student and other students. Each of them has the same position and must obtain the same treatment. Fourthly, Islamic pluralist-multicultural education gives the chances to grow and develop sense of self to every student. This is important to build self-confidence, especially for those who come from underprivileged economic classes or the relatively-isolated groups.

Islamic pluralist-multicultural education was inspired by transformative Islamic ideas. It means that Islam is always oriented to the efforts to embody Islam's aspiration; those are, forming and transforming social circumstance into Islamic aspiration; bringing mercy for 
universe. By referring to this objective, the Islamic pluralist-multicultural education aims to create a peaceful and tolerant society, and appreciating each other based on divinity values.

Multicultural education is an educational model implemented to produce educational output that has a high tolerance awareness, acceptance of differences that occur in the community and admiration of human rights. Conceptual multicultural education can be implemented as well as other educational systems, through changes in curriculum dimensions, teaching patterns and evaluation systems. Multicultural education should also be followed by an inclusive social policy of difference (Afif, 2012).

Multicultural curriculum at SMA Kartini which has been presented above can be made a model to be adapted to the learning of PAI. Although national curriculum has not contained multicultural elements, teachers of PAI can design the multicultural elements on lesson plan.

Model of learning design for Islamic multicultural-based education has three models of learning. Firstly, dogmatic approach. It is the approach seeing the religious education at schools as media of tenet transmission and certain religion's belief in "ecclesiasti-cal" way. Its goal is to embody students' dogmatic commitments towards their religions. Secondly, social studies approach, it is the approach seeing the religious education at schools as a subject like other subjects (social studies) and religious material which is taught is viewed as something secular, as anthropology and sociology do. Thirdly, social planning approach, it is the approach encouraging students' comprehension and commitment towards the religion which they adhere, and at the same time it also encourages the emergence of respecting other adherents and religious teachings to be contagious each other in plurality.

Besides the learning model as explained above, educators need to use the learning strategy to form students' attitude and behavior in context of multicultural education. According to Cushner (1993), education ought to integrate the following experiences: those are, learning how and where to obtain a goal, accurate information concerning other cultural groups; identifying and testing the positive views from groups or individuals with other cultures; learning tolerance towards heterogeneity through experimentations at school and in classroom with habits and alternative practices; dealing with, if possible, the positive experiences from the first hand with groups of different cultures; developing emphatic behaviors through role play strategy and simulation; and practicing the usage of perspective spectacles, that is, by seeing an event, history era, or issues through perspectives from groups of other cultures.

From SMA Kartini's experiences in arranging and implementing multicultural curriculum, the Islamic multicultural-based education has to take place through effective teaching and active learning by noticing students' diversity of religions. The learning process emphasizes more on teaching about religion, not teaching of religion. Teaching about religion involves historical approach and comparison, while teaching of religion involves dogmatic indoctrination approach. The learning process needs to give students the chances to actively look for, find, and evaluate their religious views by comparing them with other students' religious views. With this approach, it is expected to develop the attitude of tolerance, not judgmental, and letting go of themselves from excessive fanatical attitude.

In designing a curriculum, teachers of PAI have to accommodate all differences. The learning materials are grouped into form of theme. Teacher teaches responsibility to students to think of what activities which will be committed related to the theme. Students are given a chance to express ideas of what activities they want to do. The learning activities in the class are integrated with the theme which has been agreed together. Theme of class at SMA is adjusted with the agreement between teacher and students in each class.

The result of Harto's (2014) study on the development of multicultural-based PAI suggests philosophical paradigmatic principles for PAI teachers in multicultural teaching. These principles are to teach courage to live in differences, encourage learners to build mutual trust, 
mutual understanding and mutual respect among diverse friends, have an open attitude in thinking and acting, appreciative attitude and able to establish relationships between people/groups.

Meanwhile, Abdullah (2009) suggests that the multicultural learning requires classroom settings to be adjusted. The classroom setting is intended to provide learners with the opportunity to create a broad and convincing identity, develop a comfortable interaction, empathy and just diversity, and develop critical thinking skills and skills to defend themselves and others in the face of injustice.

\section{CONCLUSION}

SMA Kartini has successfully designed the multicultural curriculum which is integrated to subjects. The curriculum is designed to accommodate the of students' diversity. The curriculum is expected to be able to reduce the conflicts occurred among students. Model of curriculum developed by SMA Kartini and its implementation patterns can be adapted to the PAI. Subject he learning of multicultural-based PAI must take place through an effective teaching and active learning by paying attention to diversity of students' religions. Learning process emphasizes more on teaching about religion, not teaching of religion. The materials of PAI learning can be presented in form of theme covering the diversity existing in the class.

\section{BIBLIOGRAPHY}

Abdullah, A. C. (2009). Multicultural education in early childhood: Issues and challenges. Journal of International Cooperation in Education, 12(1), 159-175. Retrieved from http://home.hiroshima-u.ac.jp/cice/wp-content/uploads/publications/Journal12-1/12-1-11.pdf

Afif, A. (2012). Model pengembangan pendidikan Islam. Tadris, 7(1), 1-18. Retrieved from http://ejournal.stainpamekasan.ac.id/index.php/tadris/article/download/375/364

Alismail, H. A. (2016). Multicultural education: Teachers' perceptions and preparation. Journal of Education and Practice, 7(11), 139-146. Retrieved from http://journals.cluteonline.com/ index.php/TLC/article/view/1825

Arifudin, I. (2007). Urgensi implementasi pendidikan multikultural di sekolah. Jurnal Pemikiran Alternatif Pendidikan, 12(2), 220-233. Retrieved from https://media.neliti.com/media/ publications/70719-ID-urgensi-implementasi-pendidikan-multikul.pdf

Banks, J. A. (1993). Multicultural education : Developmnent dimensions, and callenges. Phi Delta Kappa International, 75(1), 22-28. Retrieved from http://www.jstor.org/stable/20405019

Budiman (2016, September 9). Personal communication.

Cushner, K. A. (1993). Human diversity and education: an integrative approuche. New York: McGrawHill.

Dawam, A. (2003). Emoh sekolah. Yogyakarta: Inspeal Ahimsa Karya Press.

Harto, K. (2014). Pengembangan pendidikan agama Islam berbasis multikultural. Al-Tahir, 14(2), 411-431. Retrieved from https://goo.gl/oX1i9V

Kariyawan, B. (2012). Multikultural kado untuk Indonesia. Yogyakarta: Leutikaprio.

Marintan (2016, September 9). Personal communication.

Naim, N., \& Sauqi, A. (2008). Pendidikan multikultural, konsep dan aplikasi. Yogyakarta: Ar-Ruzz Media.

Omar, N., Noh, M. A. C., Hamzah, M. I., \& Majid, L. A. (2015). Multicultural education practice in Malaysia. Procedia - Social and Behavioral Sciences, 174, 1941-1948. https://doi.org/10.1016 /j.sbspro.2015.01.859

Purba (2016, September 9). Personal communication.

Siregar, (2016, September 9). Personal communication.

Soekanto, S., \& Sulistyowati, B. (2013). Sosiologi suatu pengantar. Jakarta: Rajawali Press. 
Sugimura, M. (2015). Roles of language in multicultural education in the context of internationalisation. Educational Studies in Japan, 9, 3-15. https://doi.org/10.7571/esjkyoiku.9.3

Supardi. (2014). Pendidikan multikultural dalam pembelajaran sejarah lokal. Jurnal Pembangunan Pendidikan, 2(1), 91-99. http://dx.doi.org/10.21831/jppfa.v2i1.2621

Tilaar, H. A. R. (1999). Pendidikan, kebudayaan, dan masyarakat madani Indonesia. Bandung: Remaja Rosdakarya.

Tonbuloglu, B., Aslan, D., \& Aydin, H. (2016). Teachers' awareness of multicultural education and diversity in school settings. Egitim Arastirmalari - Eurasian Journal of Educational Research, (64), 1-28. https://doi.org/10.14689/ejer.2016.64.1

Utomo, S. S. (2016). Implementasi pembelajaran sejarah terintegrasi pendidikan multikultural. Proceedings Ilmu Sosial/Sejarah. Abstract retrieved from http://eprints.uny.ac.id/id/eprint/ 46017 